\title{
Improve the Information Technology Infrastructure at Saudi Airlines (SAUDIA) by Adapting and Implementing Agile Project Management Methodology
}

\author{
Ibrahiem T. Aseeri, Reda M.S. Abdulaal and Mohammad R. Kabli \\ Industrial Engineering Department, King Abdulaziz University, Jeddah, Saudi Arabia \\ ibrahiemtami@gmail.com
}

\begin{abstract}
This study aimed to introduce an adapted and applied Agile methodology for the Information Technology (IT) teams working at Saudi Arabian Airlines SAUDIA. The research methodology has been based on the best practices for managing the change as well as executing the managerial practices smoothly. The method development procedures were implemented using the design science research approach including problem identification, designing the proposed methodology and evaluating the case studies. The methodology included several stages, which are preparatory stage, employees' analysis stage, Agile PM methodology selection stage, agile adaptation, agile implantation and developing agility principles for SAUDIA. After that, a questionnaire was distributed amongst the agile team to evaluate their perception of the agile method. Results showed a strong relationship between the implementation of agile methods and performance of IT staff members, where members working according to agile method have better performance compared to those working according to the traditional method. The study recommended gradual adoption of agile method for the entire sectors in the SAUDIA. The study also recommended the need to involve all workers in the process of managing and executing tasks within the company.
\end{abstract}

Keywords: Information technology, Infrastructure, Saudia Airlines, Agile project management.

\section{Introduction}

Recently, Agile methodologies have been commonly executed and used worldwide. Agile methodologies are too many where there are more than 20 different one. Picking a certain methodology is subjected to the type of the project, firm as well as employees. The characteristics of employees along their motivations and relationships are among the aspects that strongly influence the success of the implementation of Agile methodologies. Therefore, these factors should be considered and evaluated when picking and adapting one of the Agile methodologies.

Like all other governmental facilities in the Saudi Arabia, SAUDIA have been working to develop agile Information Technology (IT) infrastructure in order to optimize workflow, facilitate the aviation from and to the Kingdom and to deliver e-government innovation to enhance the lives of Saudi people. This is in line with the Kingdom vision 2030. Accordingly, it is aimed to contribute to the current efforts in the field of agile adoption in the SAUDIA-IT. The implementation will be 
at Operations and Infrastructure department at the SAUDIA-IT.

In fact, it is noticed that the traditional waterfall management approach followed at the SAUDIA-IT is inefficient in terms of cost and time. Moreover, some projects have been stumbled as they were designed to be implemented using the waterfall approach. Therefore, it is very important to adopt agile approach to improve the workflow and efficiency. In the light of that, this study comes to present a methodology for adaptation and implementation of the agile PM methodology according to the project team specific at SAUDIA-IT.

\section{Literature Review}

During the 1960s, competition between business firms increased significantly and posed new challenges for the firms especially changing their work strategies. During that period, business firms were very much concerned about costs. In a later time, the priority was given to quality issues. Nevertheless, as a firm's performance depends heavily on client's satisfaction, delivery speed became as important as cost and quality. As the market became more multifaceted, customization emerged. Since then, firms this was admonished to cope with the changing work and market environment and turn out to be flexible and agile to meet the demands of the market.

In the early 1980s, the competitive priorities focused on cost, quality, and reliability. Moreover, Stalk (1988) ${ }^{[1]}$ stated that the most powerful competitive advantages were the firm's time management during the development and introduction of a new product and during sales and distribution. During that time, the notion of time-based competition has been used as an indicator of a firm's competitiveness; this translates the firm's ability to increase speed activities on the critical path ${ }^{[2]}$.

A lot of projects turn to be unsuccessful due to the low project experience level so it is clear that well-designed and tailored Project Management (PM) methodology is essential for the firm ${ }^{[3]}$. Execution of Agile Project management (PM) methods is one of the top developments in the software development restructuration ${ }^{[4]}$. Various applications of agile PM methodologies have been trialed since the announcement of an agile manifesto and diverse researchers have implemented studies showing the factors behind success/failure ${ }^{[5]}$.

The major success factors of agile PM methods are associated with individuals, training, clients, staff (number, capability, and motivation), firm culture, strategic planning, forecast, etc. Various agile methods with different types and schemes were tackled and analyzed in the literature. Some of them include Scrum, Kanban, lean software development, extreme programming, featuredriven, agile unified process, development, dynamic systems development method (DSDM) and many others. Agile methodologies attempt to describe the following disciplines: PM, project life-cycle, staff management, engineering besides delivery ${ }^{[6]}$.

Both of the traditional and agile project delivery exemplify related principles and rehearses, which aim to provide measurable results. Traditional Project Management (PM) can be described as a "waterfall" approach, which assumes the necessities, prospects, duration, activities, and products of projects could be foreseen precisely and planned in a structure before any genuine development activity are decided. With customary project delivery, the client is unable to examine the invention until the completion of the project when acceptance examination is done and 
may, possibly, expose that the product is not delivering the predictable functionality. Accordingly, the following features are typically significant boundaries of traditional project outcome in practice ${ }^{[7]}$ :

- Traditional PM is based on plans and objects whereas Agile PM focuses on customer communication and satisfaction.

- In Traditional PM, a response to change is either remedial or preventative whereas in Agile PM changes are managed by adaptive activities.

- Traditional PM is usually up-from planning whereas Agile PM is a progressive expansion with relief and iterative planning.

- In Traditional PM there is top-down controller whereas Agile PM has selforganizing and cross-functional teams.

- In Traditional PM, there is scope-based output whereas Agile PM has time-boxed output.

- Traditional PM is contract-oriented whereas Agile PM has client orientation.

The traditional project management methods have developed in the defense industries and construction engineering. However, the agile management methods have emerged as a result of the group of meetings held by a group of IT industry leaders ${ }^{[8]}$. In 2001, a group of IT professionals, who were interested in finding out better management approaches for their business firms, gathered and came up with the Agile Manifesto. This means that agile is a $21 \mathrm{st}$ management approach. The Manifesto was prepared and written professionals who used to advocate the incremental and iterative development management methods. Since the announcement of the Agile Manifesto, various developments were made in this regard and too many companies have adopted this management approach. The Manifesto outlines twelve principles for the agile management method. Table 1 presents the twelve Agile Principles (Agile Manifesto, 2001).

The agile principles show that the agile methodology is not a single method, but a set of software development methodologies that are based on the incremental and iterative approaches. The goal of these methods is to achieve customers' satisfaction and produce error-free products/services. The agile management methodologies are characterized by four qualities that are adaptive, straightforward, cooperative and incremental [9].

\section{Proposed Model Formulation and Case Study}

This section focuses the light on the methods and procedures that were proposed to develop and implement the Agile Project Management system. Moreover, Fig. 1 shows the steps for the developed system design along with all other supporting details. In order to ensure the accuracy and generalizability of the proposed methodology results, the proposed model starts with the context for the case under study followed by the suggested solution approach and the preparations for implementation.

\section{Stage 1: Preparatory Stage}

Within the preparatory stage, both firm and the staff were focused on in order to be prepared to work under the new agile methodology. A few gatherings were held with the staff to supply them with profound details around the agile management approach to encourage execution handle. The staff has been informed about the way agile method alter the physical activities at the firm as well as the way the managers think. Each of the managers who has been included within the alter handle has to be persuaded almost the agile PM technique abilities and convenience in accomplishing the goals of SAUDIA. The 
major proposed restructuration technique to prepare the SAUDIA-IT for adapting the agile PM method incorporates awareness, aspiration, ability, upgrade and exchange.

\section{Stage 2: Employees' Analysis Stage}

During the employees' analysis stage, the information was collected about the factors that contribute to the motivation of employees, interactive relationships, small groups, formal and informal managers and the conceivable agile methodology parts. Two methods were used during this stage, which are sociometric and motivation. The sociometric method included interviews focusing on the quantitative measurement of interactive associations and analysis of small social groups.

The interviews were held with the fix employees given benefits to one of the other staff members in a certain situation (formal and informal). Besides, the motivation research method used interviews to examine the motivation factors and problems based on Maslow hierarchy of needs that is the best method used to prioritize and identify the human needs.

Table 1. The 12 Agile Principles.

\begin{tabular}{|c|c|}
\hline Principle 1 & $\begin{array}{l}\text { Our highest priority is to satisfy the customer through the early and continuous delivery of } \\
\text { valuable software. }\end{array}$ \\
\hline Principle 2 & $\begin{array}{l}\text { Welcome changing requirements, even late in development. Agile processes harness change } \\
\text { for the customer's competitive advantage. }\end{array}$ \\
\hline Principle 3 & $\begin{array}{l}\text { Deliver working software frequently, from a couple of weeks to a couple of months, with a } \\
\text { preference to the shorter timescale. }\end{array}$ \\
\hline Principle 4 & Business people and developers must work together daily throughout the project. \\
\hline Principle 5 & $\begin{array}{l}\text { Build projects around motivated individuals. Give them the environment and support they } \\
\text { need, and trust them to get the job done. }\end{array}$ \\
\hline Principle 6 & $\begin{array}{l}\text { The most efficient and effective method of conveying information to and within a } \\
\text { development team is a face-to-face conversation. }\end{array}$ \\
\hline Principle 7 & Working software is the primary measure of progress. \\
\hline Principle 8 & $\begin{array}{l}\text { Agile processes promote sustainable development. The sponsors, developers, and users } \\
\text { should be able to maintain a constant pace indefinitely. }\end{array}$ \\
\hline Principle 9 & Continuous attention to technical excellence and good design enhances agility. \\
\hline Principle 10 & Simplicity is essential. \\
\hline Principle 11 & The best architectures, requirements, and designs emerge from self-organizing teams. \\
\hline Principle 12 & $\begin{array}{l}\text { At regular intervals, the team reflects on how to become more effective, then tunes and } \\
\text { adjusts its behavior accordingly. }\end{array}$ \\
\hline
\end{tabular}



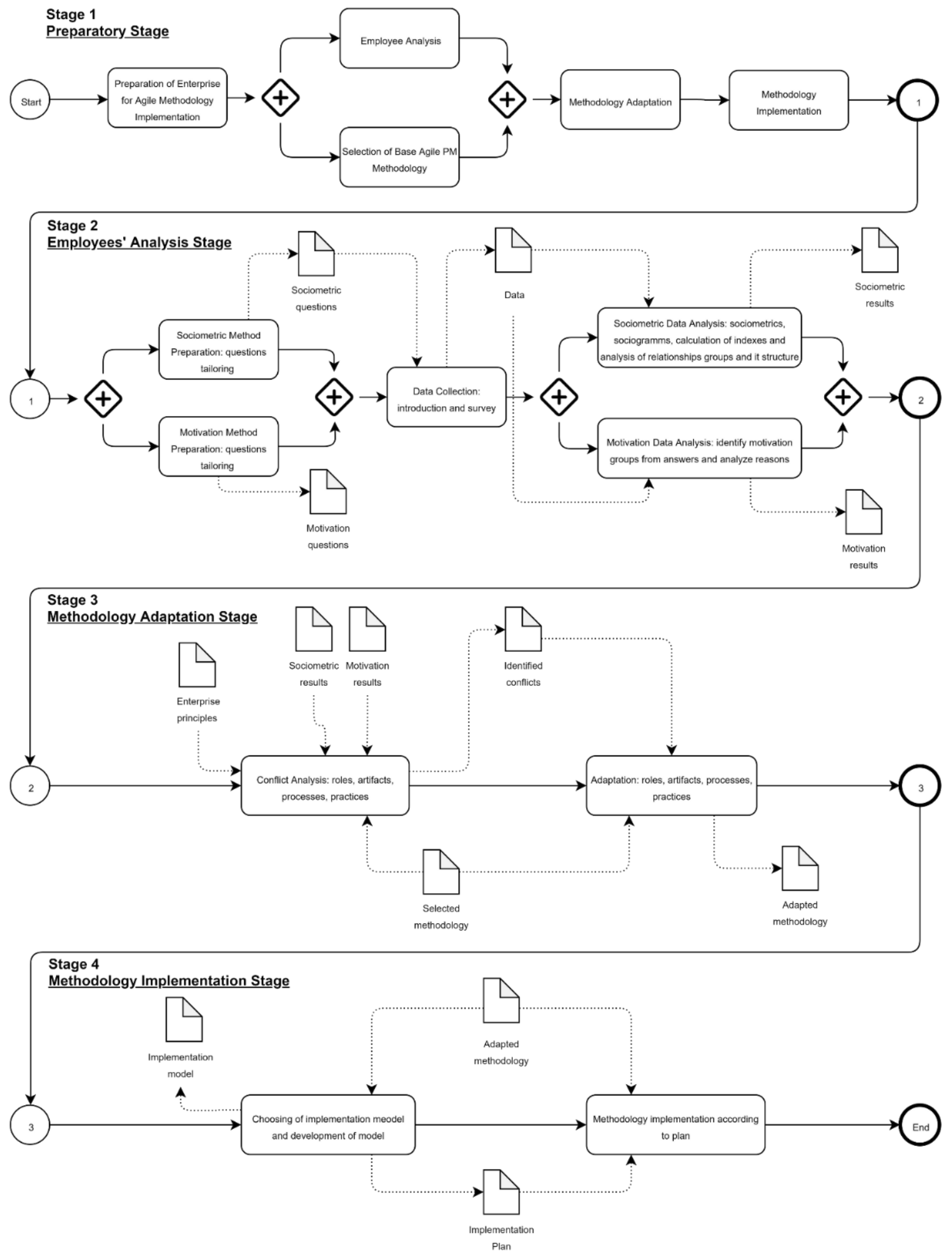

Fig. 1. The Outline of the Proposed \& Applied Agile PM Methodology. 
Both approaches follow elementary phases for interviews: Training, data collection, and data analysis. The design questions for the current situation and interview design was done throughout the preparation stages. The process for collecting data was implemented through different sources of interviews. The sociometric data analysis include the design of sociometric and sociograms, calculation of different sociometric catalogs and analysis of internal relations and the origin of it outline through the analysis.

\section{- Sociometric and Motivation Methods Preparation}

The sociometric method uses survey that focusses on quantitative measurement of interpersonal relationships and analysis of small social groups. Survey fixes employees given advantages to one of the other team members in given situation (formal and informal). The motivation research method also uses survey to analyze motivation factors and problems based on a Maslow hierarchy of needs.

\section{- Data Collection}

The data collection was done with different survey types but one of recommendations is to explain survey location and circumstances for participants during the data collection.

\section{- Sociometric Data Analysis}

The sociometric data analysis includes design of sociometrices and sociogramms, calculation of different sociometric indexes and analysis of internal relationships groups and origin of its structure using the social network analysis.

\section{- Motivation Data Analysis}

The motivation data analysis identifies groups of motives (transformation, communication, utility-pragmatic, cooperation, competition and achievement) based on Maslow hierarchy of needs from responder answers and analyzes reasons.

\section{Base agile PM methodology selection stage}

The agile method used for the current research will be developed through the base stage. According to the knowledge available, most appropriate agile method will be utilized in accordance with the Saudi SAUDIA-IT's staff and project. It was found that developing and adopting an existing method is better than developing a new one where existing methodologies have been already used in different projects. Therefore, the developments and difficulties of such methods will be known in dissimilar situations.

\section{Stage 3: Methodology Adaptation Stage}

During the methodology adaptation stage, several encounters between the nominated methodology and the characteristics of employees were analyzed. The following subsection describes the two main actions done during the methodology adaption stage.

\section{- Conflict Analysis and Adaptation}

The methodology adaptation according to requirements of project and team will help to get better results of methodology implementation. During the methodology adaptation phase conflicts between the selected methodology and enterprise principles or employees' characteristics have been analyzed and needed adaptations of the methodology have been implemented. Following elements of the agile PM methodology are needing to be analyzed during the adaptation phase: roles, artefacts, processes and practices.

Adaptation of the agile roles organized in three ways: reorganizing existing roles to agile roles; add agile roles to existing roles, and adapt agile roles to existing roles. Before 
new role implementation, need to carefully examine chosen role and its implementation possibilities. Similar adaptation approach is used for artefacts, processes and practices. There are different existing methods/ guidelines for adaptation that can be used etc.

\section{Stage 4: Methodology Implementation Stage}

Two steps are applied during the methodology implementation stage. The following subsections describe shortly these two steps:

- Choosing of implementation Model and Development of Plan

Here, in this step, the implementation model was chosen based in Deming cycle principles to help in quality improvement for the IT department at the SAUDIA as case study.

\section{- Methodology Implementation According to Plan}

The second step was to implement the model chosen by an initial evaluation with team size 10 employees from the IT department at SAUDIA. After that, the obtained agile development ideas with some Scrum PM methodology elements were used in the IT department before the case study design.

\section{Structure of Scrum Team}

In the scrum method, the employees were organized and assigned to implement one main task, which is separated into smaller tasks that could be implemented in parallel under the supervision of the Servant Leader (Project Facilitator) and 4 dedicated Team Members (IT Specialists). This is what was applied in the SAUDIA-IT.

\section{Structure of Traditional Team}

In the traditional management approach, tasks of the same project are usually implemented by different team members (IT
Specialists) who work separately and being supervised by a Team Leader (Project Manager). This is the current approach applied at the SAUDIA-IT and it was developed to be run in accordance with the agile method.

\section{Data Collection and Model Validation}

This section includes the procedures that have been used in the examination of the designed questionnaire during data collection stage. In addition, it portrays the statistical methods and treatments that have been reliable in the analysis of the data and test hypotheses to reach the results, which aims to identify method for IT infrastructure improvement at SAUDIA by adapting and implementing Agile Project Management methodology.

\section{- The Designed Questionnaire}

A questionnaire was developed and distributed amongst the SAUDIA-IT staff to evaluate the effectiveness of adaptation and implementation of agile project management methodology. This questionnaire has been designed according to five-scale, where answers are given numerical weights that present the answer degree to every statement, so it would be as follows, (Strongly agree) $=5$, $($ Agree $)=4,($ Neutral $)=3,($ Disagree $)=2$, $($ Strongly disagree $)=1$. The levels of answers according to the value of the mean and the relative weight were shown in Table 2 below. The Table provides a translation for each relative weight within the Likert scale to identify the level of agreement. To determine the minimum and the maximum length of the 5-point Likert type scale, the range is calculated by $(5-\mathbf{1}=\mathbf{4})$ then divided by FIVE as it is the greatest value of the scale $(\mathbf{4} \div \mathbf{5}=\mathbf{0 . 8 0})$. Afterwards, number ONE which is the least value in the scale was added in order to identify the maximum of this cell. The length of the cells is determined in the following Table 2. 
Table 2. Designed Questionnaire Five-Scale Distribution.

\begin{tabular}{|l|l|l|}
\hline Mean & Relative Weight & Level \\
\hline $\begin{array}{l}\text { From 1 to less } \\
\text { than 1.8 }\end{array}$ & $\begin{array}{l}\text { From 20\% to less } \\
\text { than 36\% }\end{array}$ & $\begin{array}{l}\text { Strongly } \\
\text { disagree }\end{array}$ \\
\hline $\begin{array}{l}\text { From 1.8 to less } \\
\text { than 2.6 }\end{array}$ & $\begin{array}{l}\text { From 36\% to less } \\
\text { than 52\% }\end{array}$ & Disagree \\
\hline $\begin{array}{l}\text { From 2.6 to less } \\
\text { than 3.4 }\end{array}$ & $\begin{array}{l}\text { From 52\% to less } \\
\text { than 68\% }\end{array}$ & Neutral \\
\hline $\begin{array}{l}\text { From 3.4 to less } \\
\text { than } 4.2\end{array}$ & $\begin{array}{l}\text { From 68\% to less } \\
\text { than 84\% }\end{array}$ & Agree \\
\hline From 4.2 to 5 & $\begin{array}{l}\text { From 84\% to less } \\
\text { than 100\% }\end{array}$ & Strongly agree \\
\hline
\end{tabular}

The face validity way was used to ensure the questionnaire validity and its' suitability to the research goals. The questionnaire was evaluated by a group of experts, academics and specialists. They were asked for their opinion about every paragraph in the questionnaire, and its suitability for measuring what it designed to measure. They had a chance, with given instructions, to add, delete and reformulate whatever improve the questionnaire design.

Internal consistent means consistency of each paragraph of the questionnaire with the axis that belong to that specific paragraph. Correlation coefficients has been calculated between the degree of each paragraph and the total score of the axis to which it belongs, in order to verify the validity of the questionnaire. The results indicate validity consistency of internal data in the study where values of correlation coefficient ranged for all phrases in all study axes between 0.391 to 0.824 , and these values were significant at $5 \%$ level. Table 3 illustrates this. The following analysis was done by using latest IBM SPSS Statistics trail version 25.

Table 3. Internal Consistency of Tool of the Study.

\begin{tabular}{|c|c|c|c|c|c|c|c|c|}
\hline $\begin{array}{ll}\text { No. of } \\
\text { Item }\end{array}$ & $\begin{array}{l}\text { Corr. } \\
\text { Coeff. }\end{array}$ & Sig. & $\begin{array}{l}\text { No. of } \\
\text { Item }\end{array}$ & $\begin{array}{l}\text { Corr. } \\
\text { Coeff. }\end{array}$ & Sig. & $\begin{array}{l}\text { No. of } \\
\text { Item }\end{array}$ & $\begin{array}{l}\text { Corr. } \\
\text { Coeff. }\end{array}$ & Sig. \\
\hline \multicolumn{3}{|c|}{ Corporate Culture } & 12 & $.780 * *$ & .000 & 24 & $.686 * *$ & .000 \\
\hline 1 & $.730 * *$ & .000 & 13 & $.505 * *$ & .004 & \multicolumn{3}{|c|}{ Documentation and Process } \\
\hline 2 & $.799 * *$ & .000 & \multicolumn{3}{|c|}{ Outcome and Features } & 25 & $.719 * *$ & .000 \\
\hline 3 & $.555^{* * *}$ & .001 & 14 & $.405^{*}$ & .026 & 26 & $.774 * *$ & .000 \\
\hline \multicolumn{3}{|c|}{ Governance and Control } & 15 & $.552 * *$ & .002 & 27 & $.391 *$ & .033 \\
\hline 4 & $.791 * *$ & .000 & 16 & $.717 * *$ & .000 & 28 & $.579 * *$ & .001 \\
\hline 5 & $.676 * *$ & .000 & \multicolumn{3}{|c|}{ Decisions and Information } & \multicolumn{3}{|c|}{ Interaction and Collaboration } \\
\hline 6 & $.719 * *$ & .000 & 17 & $.656 * *$ & .000 & 29 & $.681 * *$ & .000 \\
\hline 7 & $.531 * *$ & .003 & 18 & $.806 * *$ & .000 & 30 & $.665 * *$ & .000 \\
\hline \multicolumn{3}{|c|}{ Goals and Objectives } & 19 & $.824 * *$ & .000 & 31 & $.720 * *$ & .000 \\
\hline 8 & $.701 * *$ & .000 & 20 & $.783 * *$ & .000 & \multicolumn{3}{|c|}{ Agile Experience } \\
\hline 9 & $.593 * *$ & .001 & 21 & $.712 * *$ & .000 & 32 & $.423^{*}$ & .020 \\
\hline 10 & $.582 * *$ & .001 & \multicolumn{3}{|c|}{ Review and Feedback } & 33 & $.626 * *$ & .000 \\
\hline \multicolumn{3}{|c|}{ Requirements and Expectations } & 22 & $.639 * *$ & .000 & 34 & $.582 * *$ & .001 \\
\hline 11 & $.596 * *$ & .001 & 23 & $.577 * *$ & .001 & & & \\
\hline
\end{tabular}

*Significant at the 0.05 level $* *$ Significant at the 0.01 level.

\section{- Reliability Measurement}

There are many methods in which it can be measured in order to ascertain the extent of the reliability, but in this study Cronbach's Alpha method have been used to calculate the reliability in the data collected through the designed questionnaire. Table 4 shows the reliability coefficient reached, which considered good value of the Cronbach's Alpha.

Table 4. Shows the Reliability Using Cronbach's Alpha Method.

\begin{tabular}{|l|l|}
\hline No. of Items & Cronbach's Alpha \\
\hline 34 & 0.768 \\
\hline
\end{tabular}




\section{Conclusions and Recommendations}

Implementation of agile PM methodologies is related to improvement of development process: Less bugs, faster delivery, more and effective communication, better quality, better risk analysis, less over costs etc. Analyzing results of existing case study have been concluded that implementation of the Agile PM methodology is made a significant difference. With the proposed method, the study dealt with four main stages in adapting and implementing Agile PM methodologies which are preparatory stage, employees' analysis stage, methodology adaptation stage and methodology implementation stage. In the light of the research results, the following recommendations have been made:

- SAUDIA leaders are recommended to adopt Agile method throughout the entire company gradually.

- It is recommended to improve the documentation process within the SAUDIA.

- The leaders within the company are recommended to pay attention to recurrent feedback to their subordinates.

- Implementing full-scale training for the entire company is critical to ensure proper adoption of agile working method.

- Studying the impacts of agile methodologies remains a rich area for future information systems research. While this research study has been primarily exploratory in nature, it provides a number of new opportunities for future research. This study acts as a useful new data point for the research stream and provides evidence that more development and empirical research is required.
- Finally, further empirical and theoretical elaboration of the general constructs of agile method use is needed. The most obvious need is to adopt a longitudinal research design that will allow the researcher to investigate the impacts of agile methodologies over time. This would allow the field to better understand whether the impacts of agile and the moderating effects of environmental uncertainty and complexity are consistent over time.

\section{References}

[1] Stalk, G. (1988), "Time-the next source of competitive advantage”, Harvard Business Review, 66 (6): 41-51.

[2] Kumar, A. and Motwani, J. (1995). A methodology for assessing time-based competitive advantage of manufacturing firms. International Journal of Operations \& Production Management, 15(2): 36-53.

[3] Moe, N. B., Aurum, A. and Dybå, T. (2012). Challenges of shared decision-making: A multiple case study of agile software development. Information and Software Technology, 54(8): 853-865.

[4] Dybå, T., Dingsøyr, T. and Moe, N.B. (2014). Agile project management. In: Software Project Management in a Changing World (pp. 277-300). Springer, Berlin, Heidelberg.

[5] Sohi, A.J., Hertogh, M., Bosch-Rekveldt, M. and Blom, R. (2016). Does lean \& agile project management help cope with project complexity? Procedia-Social and Behavioral Sciences, 226: 252259.

[6] Conforto, E. C., Salum, F., Amaral, D. C., da Silva, S. L. and de Almeida, L. F. M. (2014). Can agile project management be adopted by industries other than software development? Project Management Journal, 45(3): 21-34.

[7] Conforto, E.C. and Amaral, D.C. (2016). Agile project management and stage-gate model-A hybrid framework for technology-based companies. Journal of Engineering and Technology Management, 40:1-14.

[8] Conforto, E.C., Amaral, D.C., da Silva, S.L., Di Felippo, A. and Kamikawachi, D.S.L. (2016). The agility construct on project management theory. International Journal of Project Management, 34(4): 660-674.

[9] Turk, D., France, R. and Rumpe, B. (2014). Limitations of agile software processes. arXiv preprint arXiv:1409.6600. 


\section{تحسين البنية التحتية لتقنية المعلومات في الخطوط الجوية السعودية من خلال تكييف وتطبيق منهجية إدارة المشاريع الرشيقة إبراهيم عسيري، و رضا عبدالعال، و محمد كابلي قسم الهندسة الصناعية، كلية الهندسة، جامعة الملك عبد العزيز، جدة، المدلكة العربية السعودية ibrahiemtami@gmail.com}

المستخلص. تهدف هذه الدراسة إلى تقديم وتكييف وتطبيق وتقييم طريقة لإدارة قسم تقنية المعلومات العاملة في الخطوط الجوية السعودية، وفقًا لمفاهيم الإدارة الرشيقة، وذلك من خلال الاطلاع على أفضل الممارسات لإدارة التغيير، وكذلك تتفيذ الممارسات الإدارية بسلاسة. وتم تنفيذ إجراءات تطوير الطريقة باستخدام منهاج علمي صحيح وواضح، تضمن تحديد المشكلات وتصميم المنهجية المقترحة وتقييم دراسات الحالة. كما تضمنت المنهجية عدة مراحل، وهي المرحلة التحضيرية، ومرحلة تحليل الموظفين، ومرحلة اختيار منهجية الإدارة الرشيقة التي تم تطبيقها، ومرحلة تكييف منهجية الإدارة الرشيقة التي تم اختيارها، وكذلك مرحلة التتفيذ وتطوير معايير ومبادئي خاصة للخطوط الجوية السعودية التي تستتد على منهجية الإدارة الرشيقة. بعد ذلك، تم توزيع استبيان بين أعضاء الفريق الذين قاموا بأداء وظائفهم وفقًا لمنهجية الإدارة الرشيقة، وذلك لتتييم آراؤهم وانطباعهم حول الأسلوب الإداري الجديد. وأظهرت النتائج وجود بأن علاقة قوية بين تتفيذ الإدارة الرشيقة وأداء موظفي قسم تقنية المعلومات، إذ يكون أداء الأعضاء الذين يعملون وفقًا للطريقة الجديدة أفضل مقارنة بالأعضاء الذين يعملون وفقًا للطريقة التقليدية. كما أن إشراك الموظفين في إدارة وتتفيذ المشاريع بطريقة تعاونية تعود بالنفع على إدارة الثركة ككل. وقد أوصت الدراسة بالتبني التدريجي لطريقة الإدارة الرشيقة في كافة أقسام مؤسسة إدانة الخطوط الجوية السعودية، كما أوصت الدراسة بضرورة إشراك كافة العاملين في عملية إدارة وتتفيذ المهام داخل الثركة. كلمات مفتاحية: تقنية المعلومات، البنية التحتية، الخطوط الجوية السعودية، إدارة المشاريع الرشيقة. 